\title{
Does Rorty have a Blindspot about Truth?
}

\author{
David Macarthur
}

\section{(2) OpenEdition}

\section{Journals}

Electronic version

URL: http://journals.openedition.org/ejpap/1851

DOI: 10.4000/ejpap.1851

ISSN: 2036-4091

\section{Publisher}

Associazione Pragma

\section{Electronic reference}

David Macarthur, « Does Rorty have a Blindspot about Truth? », European Journal of Pragmatism and American Philosophy [Online], XII-1 | 2020, Online since 16 June 2020, connection on 26 June 2020. URL : http://journals.openedition.org/ejpap/1851 ; DOI : https://doi.org/10.4000/ejpap.1851

This text was automatically generated on 26 June 2020.

\section{(c) (i) $\odot$}

Author retains copyright and grants the European Journal of Pragmatism and American Philosophy right of first publication with the work simultaneously licensed under a Creative Commons AttributionNonCommercial-NoDerivatives 4.0 International License. 


\title{
Does Rorty have a Blindspot about Truth?
}

\author{
David Macarthur
}

1 Richard Rorty has often been criticized as having a blindspot about the normative role of truth. To give three prominent examples: John McDowell criticizes Rorty for missing the normativity embedded in the disquotational use of truth; ${ }^{1}$ Hilary Putnam accuses Rorty of a sophisticated relativism, which fails to take seriously the objective normativity of truth, the way in which truth transcends communal standards. ${ }^{2}$ And Huw Price argues that on Rorty's view of truth one is unable to make sense of the idea that a speaker, warranted by her own lights, could improve her commitments by consulting the commitments and justificatory practices of the wider community. Of these Price's criticism is perhaps the strongest and the one I would like to critically examine in this paper. ${ }^{3}$

2 Variants of Price's criticism have also been voiced by other well-known philosophers (e.g. Habermas ${ }^{4}$ ) and it is initially quite compelling. If we do not recognize a truth that transcends our practices and the agreements that are forged within them, then what could motivate us to improve our commitments if they meet the only operative standard in the vicinity, namely, being accepted by one's own standards, say, of coherence?

3 My aim in the present paper is twofold: in the first place, I want to respond on Rorty's behalf to Price's conception of where Rorty's blindspot about truth lies. I shall argue that Price's criticism is off-target missing the perfectionist character of the justificatory norms that are criterial for truth. Secondly, I want to argue that despite sidestepping Price's criticism, Rorty does indeed have a blindspot which concerns the way in which truth figures in internal reflection upon a system of beliefs, e.g., 1stperson reflection upon one's own system of belief. For the most part Rorty exclusively focuses upon truth and justification as norms of belief maintenance in a critical communal setting; and even when he accepts that there are other contexts in which the question of truth is at issue he tends to model them on justification to one's peers. 


\section{Rorty on the Normativity of Justification}

4 In articulating his own pragmatist account of truth as a "convenient friction" that makes disagreements matter, Huw Price argues that Rorty - whose antirepresentationalist outlook inspired his own - has a blindspot about the normativity of truth. ${ }^{5}$ In particular, Price accuses Rorty of failing to acknowledge that truth is a third norm apart from the norms of sincerity and personal justification. As a consequence, Price claims, Rorty is unable to make sense of the idea that an individual speaker, warranted by her own lights, could improve her commitments by consulting the commitments and justificatory practices of the community. Or, rather, to bring the argument directly to bear on Rorty: Rorty is unable to make sense of the idea that communal justification, which is warranted by its own lights, could improve its commitments by consulting the commitments of a broader better informed or more critically astute community.

5 It is worth observing that Price's objection cannot be that Rorty refuses to admit that truth plays some normative role or other. Rorty follows Davidson in holding that the concept of truth is part of a package-deal of concepts including belief and meaning that is required to make sense of the idea of rational agents rationally responsive to both their natural-causal and social-linguistic environments. Truth is a norm at least in the sense that it is a standard in terms of which we assess beliefs. That is the insight in the thought that belief "aims at" the truth. Criticizing a belief by saying "That's not true" or praising a belief by saying "That's true" have prima facie normative implications: the first puts some pressure on the believer to give up the belief or at least to defend it with appropriate reasons; the latter gives some (additional) reason to stand by the belief in the face of criticism. Rorty calls these respectively dis-endorsing and endorsing uses of the term "true."

6 Price's criticism, then, cannot be that truth for Rorty plays a purely disquotational role without any normative import - a criticism he has levelled at Paul Horwich. ${ }^{6}$ Rather what Price objects to is Rorty's view that truth is not a distinct norm whose function is independent of that of justification. Rorty takes it that the normative role of truth can be exhaustively spelled out in terms of norms of communal justification, actual and possible. Justification is, on Rorty's view, our best criterion for what counts as true but he admits that the latter is not reducible to the former. As Rorty puts it, "Granted that 'true' is an absolute term [in so far as truth is not relative to purposes, times or places], its conditions of application will always be relative [in so far as justification is relative to purposes, times and places]." So Rorty understands the endorsement or disendorsement of a belief as true, or not, as a way of expressing whether the belief in question is accepted as appropriately justified in one's community. Rorty's attitude to the normativity of truth is summed up in the following remarks:

The only difference between truth and justification which makes [...] a difference is, as far as I can see, the difference between old audiences and new audiences [...]

I think that, once one has explicated the distinction between justification and truth by that between present and future justifiability, there is little more to be said. ${ }^{8}$

Apart from disquotational and endorsing uses of the term "true" Rorty recognizes a cautionary use in such expressions as "Your belief is fully justified but it may not be true." Of the three uses of the word "true" the cautionary use is the only indispensable one. But, as one might expect, Rorty refuses to see this as granting any independent 
normative status to the concept of truth. He interprets cautionary uses of "true" in terms of a distinction between what is justified according to current communal norms and what is justified according to an idealized community: one that is better-informed, more demandingly critical or richly imaginative than ours. Idealization here is to be understood as idealization from the perspective of our current lights; it is idealization without a transendent ideal or limit concept. Rorty's incrementalist progressive approach to justification only requires that we can always imagine the possibility of an improvement in our standards of belief-formation and assessment. ${ }^{9}$ But this is precisely what Price argues Rorty is not entitled to assume without the addition of a distinctive norm of truth.

\section{A Rortian Response to Price}

8 As we have seen, Price argues that Rorty's norm of communal warranted assertibility suffers the same fate as the norm he calls personal warranted assertibility, namely, that without a distinct norm of truth neither norm can make sense of improvements in one's epistemic standing whether in terms of the actual community or future extensions and improvements of it. But this alleged incoherence is based on treating the norm of communal warranted assertibility as a static norm rather than the revisable update-able norm that Rorty intends. Price treats satisfaction of both norms of warranted assertibility as equivalent to getting full marks on an exam - a model which, of course, leaves no room for improvement. But a better analogy would be determining the number of moons of Jupiter with Galileo's telescope - a case that allows that a bigger better telescope might be capable of finding more moons; and so providing a better answer to the question.

Price's misreading here is closely related to a familiar misinterpretation of Rorty as having a majoritarian conception of justification according to which one is justified in a belief if it would be accepted by a majority of one's communal peers. ${ }^{10}$ This majoritarian reading would indeed make allowance for one to meet the norm of justification in a given community - by being part of its majority opinion - without caring in the least about a different consensus within another better informed community. In that case Price's criticism that there would be no normative pressure to improve would go through. It is in virtue of more or less the same argument that Price motivates his introduction of a distinct norm of truth to make disagreements matter.

10 To get Rorty straight here we need to draw a distinction between a static (say, majoritarian) and a progressive perfectionist conception of communal norms. Perfectionist norms of justification are implicit in our practices of inquiry: that is, norms of justification that appeal to our best information, our best investigative techniques and our best arguments. Such norms are not, for Rorty, a matter of counting heads within a fixed well-defined group but, rather, doing the best we can along the dimensions of information, investigation and argument wherever, whenever and however we can. What we count as best, of course, changes as we acquire more and better information, more and better investigative techniques and more and better arguments. ${ }^{11}$

11 It is important to note, in addition, and in spite of some of Rorty's rhetoric, that the relevant notion of community is not to be understood in general as a more or less stable cultural or political entity but as a plastic epistemic one defined for each specific 
subject matter in terms of those whose information, and techniques of investigation and arguments are most relevant for the case at hand..$^{12}$ For example, if it is a question about the sub-structure of the atom then researchers who work in physics departments and laboratories around the world contribute to determining what we count as best justified on the matter. If it is a question about the artistic value of a painting then those with experience and good judgment about paintings (those with, as we say, "good taste" in this visual art) are part of the relevant community of peers.

Another way to make the same point is to see that Rorty's deference to communal norms of justification is a version of Dewey's theory of inquiry - itself a liberalization of Peirce's theory. It is well-known that Peirce treats beliefs as part of a default-andchallenge structure of truth-commitments..$^{13}$ On this model one is default entitled to a belief that is part of one's evolving worldview unless and until there is some good reason to doubt it. Peirce appeals to what he calls (somewhat misleadingly) "the scientific method of inquiry" as the best means to settle opinion on some disputed matter. ${ }^{14}$ On Dewey's elaboration of this approach "the scientific method" is understood as a form of democratic experimentalism, a set of quasi-moral quasi-political principles of virtuous inquiry combined with a fallibilist experimental attitude that is just as applicable to art criticism and moral or political dilemmas as to problems in chemistry, economics and paleontology. The scientific method in this sense is not exclusively a method of the successful empirical sciences, just one that the natural sciences happen to best exemplify. On this view, beliefs are to be understood as justified in terms of perfectionist epistemic norms implicit in our best practices of inquiry where the implicit reference to a "we" is understood in terms of expertise or good taste or some other normatively-laden grouping based on relevant training, experience and good judgment.

13 A person who meets the norms of communal warranted assertibility within a particular community is, contrary to Price's criticism, put under immediate normative pressure to adjust or change his or her views in light of better information and argument and more critically robust methods of inquiry. Consequently, Price's criticism of Rorty misses its target since it is aimed at a static view of communal justification of which majoritarianism about justification is one familiar example.

Nonetheless, although Rorty can avoid Price's criticism, I now want to argue that there remains a residual problem for his conception of the normative role of truth - even if we grant with him that truth is not a separate stand-alone norm wholly distinct from matters of justification.

\section{Rorty's Blindspot}

On Rorty's view while truth cannot be reduced to justification, justification is our best criterion for truth. Or, more fully, justification within the relevant epistemic community is our best criterion for truth. That is to say, it is on the basis of appropriate justification that we count something as true. And while truth is a normative notion in so far as it is a standard according to which beliefs are assessed it is not a distinctive norm since we must often appeal to our norms of justification to determine what it true. It is for this reason that Rorty denies that truth is an independently identifiable goal of inquiry at which we might aim. If we can only determine truth by way of what is best justified and what is best justified is, as Rorty puts it, "an ever-retreating goal" 15 
in so far as it is likely, based on a plausible induction from the past, that we will in the future discover more and better information, arguments, and criticism - then there is no fixed something called "truth" for inquiry to locate and aim at.

But even if we accept this general picture of truth there still remains a question about whether the normative function of truth is exhausted by appeal to the norms of communal justification. We can approach this matter by considering the following passage in which Rorty is discussing the term "true":

I see no significance in the fact that we use the same word to designate what is preserved by valid inference as we use to caution people that beliefs justified to us may not be justified to other, better, audiences. ${ }^{16}$

Here Rorty distinguishes two different jobs that truth does for us: 1) to single out what is preserved in valid inference (by which I take him to mean valid argument); and 2) to caution people that no matter how well justified they are it is possible that this justification may not hold for a better informed more critically sophisticated audience. In the outward perspective of inquiry truth is a norm regulating the formation of new beliefs, the answering of new questions, the resolution of new doubts. In these sorts of cases Rorty argues that both the endorsing and cautionary uses of truth can be plausibly interpreted in terms of norms of justification to one's peers: in the first case one expresses solidarity with the norms of justification of one's interlocutor(s); and in the second case one imagines a contrast between conforming to the norms of one's actual community and those of a better one, at least from the epistemic perspective.

When Rorty considers the question of truth's normativity he tends to focus his attention almost exclusively on the perspective of inquiry where the question concerns justifying one's beliefs to one's peers in the setting of a communal activity. What this shows is that although Rorty is careful not to reduce the concept of truth to that of justification or verification (as he is often accused of doing ${ }^{17}$ ) he does have a tendency to reduce the normativity of truth to the normativity of justification to one's peers. ${ }^{18}$ Whatever normativity truth has is, on Rorty's view, borrowed from that of justification and idealizations of such. That there is a blind-spot here is evident, I take it, from Rorty's inability to see the connection between the truth-preservingness of valid implication - what we might think of as the systematicity of truth - and the question whether our ostensible beliefs are sufficiently justified to form part of our system of truth-commitments. ${ }^{19}$ That is, both valid implication and justification play important roles in the maintenance and revision of a world-view understood as an evolving system of truth-commitments rationally responsive to each other and to the empirical world.

The normativity of truth is not, as Rorty often seems to suppose, reducible to the normativity of justification. To see this consider that in order to have a system of beliefs at all our truth-commitments must be bound by a rational norm of consistency. ${ }^{20}$ Of course, we must not think of this as merely a linguistic norm concerning speech acts for it is equally applicable to unexpressed beliefs or judgments. We may put the norm as follows:

20 Norm of Consistency: If one judges that not-P and also judges that $\mathrm{P}$ - or there is a plausible inference from one's current beliefs to the conclusion that $\mathrm{P}$ - then one must adjust one's commitments to remove the inconsistency.

21 Complying with the norm of consistency is something that we require of any rational system of beliefs or truth-commitments - this is part of what makes it rational. And, 
significantly, when reflecting upon our beliefs we do not suppose that we can treat this norm as a matter of justification to one's peers. One must comply with this norm quite independently of any question of justification for specific commitments. For example, it applies to beliefs that one did not form on the basis of deliberation as well as to beliefs one continues to hold despite having forgotten the basis or justification upon which one came to believe them. And where conflicting beliefs are held it tells us that we cannot continue to hold both beliefs prior to any comparison of the relative strength of their respective justifications, supposing that we are aware of such.

The norm of consistency is a principle of belief revision related to reasoned change in view in contrast to the law of non-contradiction (i.e. it is not the case that $\mathrm{P}$ and that not-P) which is a matter of formal logic. The norm of consistency concerns rational inference, what it is reasonable or not to believe in light of what one already believes, rather than simply logical implication, what logically follows from what - which puts constraints on the structure of our truth-commitments without prescribing what to believe. ${ }^{21}$ Following the norm of consistency is part of what is required to achieve the rational integration of one's truth-commitments. ${ }^{22}$ In so far as one has a world-view that is inferentially articulated (constrained though not determined by the laws of logic) and rationally responsive to the empirical world (including the social world) then, as Gil Harman puts it, "one always has a reason to avoid inconsistency." ${ }^{23}$

The norm of consistency, which is better understood in terms of avoiding inconsistency if and when it arises rather than of striving for consistency, applies at the social level too. ${ }^{24}$ For example, consider Price's norm of truth:

Norm of Truth: if Not-P then it is incorrect to assert that P; if Not-P there are prima facie grounds for censure of an assertion that $\mathrm{P}$.

This can be understood as a social version of the norm of consistency, one which presupposes a notion of social reason and a normative demand to achieve a unified world-view amongst fellow speakers (or, at a minimum, fellow speakers within the same field or specialization) within a society - at least about matters where we do not tolerate "no-fault disagreements." ${ }^{25}$ Such a norm may be thought to function as a regulative ideal of human communicative practices. Again, it seems right to say, as Price does, that the normative force of the norm of truth, as he calls it, does not depend on any specific considerations of justification for given commitments. But that is not to say that Rorty is wrong to deny that truth is an additional norm of the sort that Price imagines, one wholly distinct from justification.

What it shows is that Rorty routinely mischaracterizes the normativity of truth. The problem can be traced to Rorty's inability to see why truth should be involved in both logical implication and justification to one's peers (especially when we caution others that what is justified to them might not be justified to other better informed audiences). ${ }^{26}$ What Rorty is seeing, I suggest, is only one half of the Janus-faced relation between truth and reason. By focusing exclusively on the public reason-giving dimension of the relation Rorty misses its personal or reflective dimension. Public justification that provides reasons to support a commitment (perhaps as a response to a question or doubt) is the external face of reason in its maintenance of a relatively stable world-view in a context of disputes, disagreements and arguments. But there is also the internal face of reason in 1st-personal or social reflection on the unity of one's (or our) world-view which shows up as a demand for consistency (that is, a demand to eliminate inconsistency) in one's (or our) thinking quite independently of matters of 
justification to one's peers or even justification to oneself in self-reflection. To come to appreciate that two truth-commitments are inconsistent, either because they are logically inconsistent (in so far as they cannot both be true together) or because there is a plausible argument to that conclusion, is to see that one or the other must be given up. It is a further question whether one has any better justification for one than for the other.

Notwithstanding this blindspot, Rorty's does have a genuine insight, namely, that truth is not "an additional norm" that we might have done without. ${ }^{27}$ This is the mistake Price arguably makes. Over-generalizing Wittgenstein's comparison of the functions of words with "tools in a toolbox" Price conceives of our ordinary concept of truth as a tool that makes disagreements matter - a tool designed for a specific function that we can imagine having done without. ${ }^{28}$ To highlight this instrumental approach, Price devises a thought-experiment according to which there is a so-called Mo'an tribe whose members enjoy speech and reason and conform to the norms of subjective assertibility (sincerity) and personal warranted assertibility (justification by one's own lights) which he elucidates thus:

Subjective Assertibility: A speaker is incorrect to assert that $\mathrm{P}$ if she does not believe that $\mathrm{P}$; to assert that $\mathrm{P}$ in these circumstances provides prima facie grounds for censure, or disapprobation.

Personal Warranted Assertibility: A speaker is incorrect to assert that $\mathrm{P}$ if she does not have adequate (personal) grounds for believing that $\mathrm{P}$; to assert that $\mathrm{P}$ in these circumstances provides prima facie grounds for censure.

What Mo'ans lack is the concept of truth. By picturing Mo'an practices before and after the introduction of the concept of truth Price aims to isolate and identify the function of truth and the difference it makes to our practices. In a more sophisticated version of the thought-experiment, Mo'ans are granted a truth predicate, but lack "the norm of truth." Their "truth" predicate operates as a mere device of disquotation without any normative force. As Price imagines it, Mo'ans in this scenario have a practice of expressing merely opinionated assertions (from whence their name is derived) which do not critically engage with one another - much like personal preferences for food (e.g. dark chocolate) or drink (e.g. guinness).

31 An immediate problem with Price's thought experiment is that it is obviously incoherent - a point Price himself now concedes. ${ }^{29}$ All the key terms in which Price describes the Moans prior to having the concept of truth - such as opinion, disagreement, assertion - simply presuppose the concept of truth. For example, to be of the opinion that $p$ is to take $p$ to be true. To disagree with someone about their assertion that $p$ is to take $p$ to be false. And the same point applies to the more sophisticated version of the thought-experiment too: all the terms in which the Mo'ans are described presuppose a normative concept of truth rather than a merely disquotational one. So a disagreement that did not put some prima facie pressure upon one to defend one's belief or to criticize one's interlocutor's contrary belief would not be a disagreement at all but, at best, a mere difference. Consequently, the threat of vicious circularity that Price acknowledges, vitiates his thought experiment and its explanatory point. ${ }^{30}$ The description of the Mo'ans before they have the normative concept of truth is one that simply presupposes what it is being used to explain i.e. the normative concept of truth.

That the Mo'an thought-experiment is more or less obviously incoherent shows that truth cannot be treated instrumentally as a stand-alone norm fulfilling a distinctive 
function which might be sensibly substracted from and then added to linguistic practice in the way Price supposes. ${ }^{31}$ As Rorty, following Davidson, saw, truth is part of a package-deal of fundamental concepts including reason, meaning and belief no one of which can be explained without invoking the others. Truth is implicated in the very ascription of beliefs and meanings to speakers - rational agents with communicative intentions - given the principle of charity in interpretation that implies a general presumption of rationality when interpreting another speaker.

Consequently, an important moral of the Price-Rorty exchange for a neo-pragmatist approach to truth is that it is a mistake to treat truth as doing "a distinctive job" in our thought and talk that we might imagine having done without. ${ }^{32}$ One cannot instrumentalize truth as if it were an isolable tool performing a function in terms that do not presuppose it. Despite Rorty's blindspot about the normativity of truth, his awareness of the deep and inextricable embeddedness of truth in our linguistic and interpretative practices - which undermines Price's Mo'an thought-experiment - is an important insight that survives criticism.

\section{BIBLIOGRAPHY}

BRANDOM Robert (ed.), (2000), Rorty and his Critics, Oxford, Blackwell.

CAVELL Stanley, (1979), The Claim of Reason, Oxford, Oxford University Press.

DE CARO Mario \& David MACARTHUR (eds.), (2010), Naturalism and Normativity, New York, Columbia University Press.

HABERMAS Jürgen, (2000), “Richard Rorty's Pragmatic Turn," in Robert Brandom (ed.), Rorty and his Critics, Oxford, Blackwell, 31-55.

HARMAN Gil, (1986), Change in View, Cambridge, MIT Press.

KANT Immanuel, (1998), Critique of Pure Reason, ed. Paul Guyer \& Allen Wood, Cambridge, Cambridge University Press.

KANT Immanuel, (2000), Critique of the Power of Judgment, ed. Paul Guyer, Cambridge, Cambridge University Press.

MACARTHUR David, (2015), “A Kant-Inspired Conception of Pragmatism as Democratic Experimentalism," in Gabriele Gava \& Robert Stern (eds.), Pragmatism, Kant \& Transcendental Philosophy, London, Routledge, 67-84.

MCDOWELL John, (2000), “Towards Rehabilitating Objectivity,” in Robert Brandom (ed.), Rorty and his Critics, Oxford, Blackwell, 109-23.

MISAK Cheryl, (2000), Truth, Politics, Morality, London, Routledge.

MISAK Cheryl, (2006), "Charles Sanders Peirce (1839-1914)," The Cambridge Companion to Peirce, Cambridge, Cambridge University Press, 1-26.

MISAK Cheryl, (2013), The American Pragmatists, Oxford, Oxford University Press. 
PEIRCE Charles Sanders, (1955), “The Fixation of Belief," in Philosophical Writings of Peirce, ed. Justus Buchler, New York, Dover, 5-22.

PRICE Huw, (2010), "Truth as Convenient Friction," in Mario De Caro \& David Macarthur (eds.), Naturalism and Normativity, New York, Columbia University Press, 229-52.

PRICE Huw, (2011), Naturalism without Mirrors, Oxford, Oxford University Press.

PUTNAM Hilary, (1992), Renewing Philosophy, Cambridge, MA, Harvard University Press.

PUTNAM Hilary, (2000), "Richard Rorty on Reality and Justification," in Robert Brandom (ed.), Rorty and his Critics, Oxford, Blackwell, 81-7.

RORTY Richard, (1979), Philosophy and the Mirror of Nature, Princeton, Princeton University Press.

RORTY Richard, (1993), “Putnam and the Relativist Menace," Journal of Philosophy, 90 (9), 443-61.

RORTY Richard, (1995), “Is Truth a Goal of Inquiry? Davidson vs Wright,” The Philosophical Quarterly, 45 (180), 281-300.

RORTY Richard, (1998), Truth \& Progress: Philosophical Papers vol. 3, Cambridge, Cambridge University Press.

RORTY Richard, (2000), "Universality and Truth," in Robert Brandom (ed.), Rorty and his Critics, Oxford, Blackwell, 1-30.

RORTY Richard, (2000), "Response to Jurgen Habermas," in Robert Brandom (ed.), Rorty and his Critics, Oxford, Blackwell, 56-64.

WITTGEnSTEIN Ludwig, (2009), Philosophical Investigations, 4th ed., Hacker P. M. S. \& Joachim Schulte, Oxford, Blackwell.

\section{NOTES}

1. McDowell (2000: 109-22).

2. Putnam (1992: 67-71).

3. In response to McDowell (2000), Rorty can agree that a disquotational use of the term "true" may also be an endorsing use - without glossing that in terms of answerability to the world. Whether it is necessarily so, as McDowell argues, is something for further debate. And in response to Putnam, Rorty distinguishes ethnocentrism - the view that our thought and talk is inevitably embedded in a cultural and social context - from relativism about truth. It is only the former view that he endorses. See Rorty (1993).

4. Habermas (2000: 32) writes, "Rorty assimilates truth to justification at the expense of everyday realist intuitions."

5. Price (2010).

6. Price (2010: 167).

7. Rorty (1998: 2).

8. Rorty (2000: 4-5).

9. Somewhat surprisingly, Rorty's account of justification is analogous to Peirce's incrementalist convergence account of truth which Rorty roundly criticizes. In both accounts there is a tension between present commitment and possible future revision. In Rorty this is the tension between the endorsing use of "true" underwritten by current standards of justification and the cautionary use of "true" underwritten by possibly better standards in the future. For Peirce, truth is what stands up to present scrutiny (hence we can endorse what now looks satisfactory to believe by 
our current lights) but it must also stand up to future scrutiny (hence we might be mistaken in what we now take to be true although we hope that we are not).

10. This is how Putnam, e.g., reads Rorty on the ground that, for Rorty, justification is a sociological matter. See Putnam (2000: 84).

11. Rorty appeals to "curiosity," and "concrete fears of regression" in order to explain what motivates one to engage in further inquiry even if one has satisfied communal standards of justification. Rorty (2000: 17, 61).

12. Rorty speaks of "justifying our belief to the audience we think relevant (perhaps our own intellectual conscience, or our fellow-citizens, or the relevant experts)" (ibid.: 56). In referring to an "epistemic community" I am aware that pragmatists politicize epistemology in so far as the theory of inquiry concerns a community of inquirers ideally operating according to relations of trust, openness, sincerity, respect, and toleration.

13. Peirce, "The Fixation of Belief."

14. I have discussed this notion of scientific method as a method that is not exclusive to the sciences and defended its philosophical importance against Rorty's criticisms in "A Kant-Inspired Conception of Pragmatism as Democratic Experimentalism" (2015).

15. Rorty (1995: 298). Rorty's point here expands into an argument against Misak's Peircian account of true belief as "a belief that could not be improved upon, a belief that would forever meet the challenges of reasons, argument and evidence" (Misak 2000: 49). Another more succinct formulation: "A true belief is a permanently settled or indefeasible belief" (Misak 2006: 7). To identify true belief with indefeasible belief in this way is to make truth hostage to fortune and put it out of reach of our practices - an unintended unpragmatic consequence. Since in any given case one cannot know whether a putatively true belief will meet all the challenges of reasons, argument and evidence in the future then we cannot claim it to be true now. We simply have no way of knowing whether a belief is indefeasible or not. Rorty's alternative, to say that justification is the criterion of truth, without identifying truth with anything, allows one to take hold of truths in the present; and it allows for the fallible updating of truths as one's justifications change for the better as a result of better reasons, argument and evidence.

16. Rorty (1995: 286).

17. For example, even Misak, who is more careful than most in this regard, claims that "[Rorty] asserts that 'truth' and 'objectivity' are merely labels for what our peers will let us get away with saying." Although the passage that Misak is paraphrasing is Rorty at his most rhetorical, she leaves out the crucial qualification "ceteris paribus" in the original text i.e. Rorty (1979: 176). Misak (2013: 30).

18. Occasionally, Rorty demonstrates an awareness that there is more to the normativity of truth than that. Consider this passage: "The need to justify our beliefs and desires to ourselves and to our fellow-agents subjects us to norms, and obedience to these norms produces a behavioural pattern which we must detect in others before confidently attributing any beliefs to them. But there seems to be no occasion to look for obedience to an additional norm, the commandment to seek the truth. For [...] obedience to that commandment will produce no behaviour not produced by the need to offer justification." (1995: 287).

What I want to draw attention to is Rorty's awareness that we justify beliefs and desires "to ourselves." But the insight is immediately obscured since Rorty treats the 1st-person case of reflection on the model of justification within a community of peers: that is, one's own "intellectual conscience" is considered to be an audience that one must convince. But there are important differences between the 1st-person deliberative case of making up one's mind and providing justification to others: 1 ) others can simply not listen in a way that has no analogue in one's own reflections; 2) in the case of a genuine audience one is not in a position to make up their minds for them no matter how overwhelming the justifications might seem to us; and 3) in the 1st-person case it can be responsible to maintain a belief that one already holds even if one 
does not know what would justify it. If one already believes then justification to oneself is irrelevant.

19. Rorty (1998: 25, fn 23).

20. We could also speak of this as a "logical" norm if we understand this term in the broad sense that Wittgenstein uses it when he speaks of his philosophical investigations as concerning "the logic of language," e.g. (2009: § 93).

21. For a detailed discussion of the importance of the distinction between inference and implication see Gil Harman's Change in View (1986). Note, too, that in the quoted passage on p. 8 Rorty uses the term "inference" for what I am calling "implication".

22. This is what Kant, from a "pure" a priori perspective (that a pragmatist would want to bring down to earth), calls the "transcendental unity of apperception" (2000: B139).

23. Harman (1986: 56).

24. Kant, e.g., recognizes social and personal dimensions of the norm of consistency. Two of the three maxims of "the common human understanding" (sensus communis) are: "always to think in accord with [or consistently with] oneself"; and "to think in the position of everyone else" (2000 5: 294).

25. This is Price's expression (e.g. 2011: 47). It might be better to speak of "no-blame disagreements" since one might not blame another for thinking what one takes to be false in, say, aesthetic, moral or political matters given their different sensibility, upbringing, self-image (etc.). But one might still find fault in the sense that one thinks they are missing something. Cavell calls such cases matters of "rational disagreement" which registers the fact that there can be, in a sense, equally legitimate but conflicting rational responses to an artwork or a moral or political conundrum. Cavell (1979: 254).

26. Rorty (1998: 25, fn 23).

27. Price (2011: 164).

28. Wittgenstein remarks: "Think of the tools in a toolbox: there is a hammer, pliers, a saw, a screwdriver, a rule, a glue-pot, glue, nails and screws. - The functions of words are as diverse as the functions of these objects. (And in both cases there are similarities.)" (2009: § 11).

29. Price (2010). Price is unfazed by the admission since he appeals to the incoherence as itself a demonstration that truth plays the distinctive normative role of "making disagreements matter" that the Mo'an thought experiment was originally intended to isolate. But all he is entitled to conclude from the incoherence of the case of the Mo'ans is that the concept of truth (including its normative dimension) is not independent of the concepts (hence the normativity) of justification, belief, assertion, reason, and meaning.

30. Price admits that "circularity threatens" in various places in his account of the Mo'ans although it also seems clear that he originally believed that it could be avoided (2011: 176, fn 17).

31. Price's instrumentalist assumption that truth performs a distinctive stand-alone function is clear from his attempt "to imagine a linguistic practice which had those norms [of sincerity and personal justification] but not truth. By seeing what such a practice lacks we see what truth adds" (2011: 168). As originally conceived Price was of the view that if we subtracted the norm of truth we would still be left with intelligible linguistic practices, albeit "radically different" (ibid.: 166). He remarks: "Without truth the wheels of argument do not engage; disagreements slide past one another" (ibid.: 179). But all we are entitled to say here is that without truth there would be no such thing as argument or disagreement.

32. (Ibid.: 174). 


\section{ABSTRACTS}

Criticisms of Rorty's view of truth are so frequent and from such sagacious sources that it is reasonable to suspect that there must be some truth in them. But what? In this paper I consider perhaps the strongest form of such criticism, Huw Price's claim that without a distinct norm of truth Rorty is unable to make sense of how someone, justified by her own lights (say, local communal standards), could improve her commitments by reference to another better informed community. My aim in the present paper is twofold: In the first place, I shall argue that Price's criticism is off-target missing the perfectionist character of the justificatory norms that are criterial for truth on Rorty's account. Secondly, I argue that Rorty's actual blindspot concerns the way in which truth figures in internal reflection upon a system of beliefs, e.g., 1st-person reflection upon one's own beliefs. But this blindspot should not blind us to the lasting insight in Rorty's resistance to Price's attempt to instrumentalize truth as if it were an isolable tool of our linguistic practices.

\section{AUTHOR}

\section{DAVID MACARTHUR}

University of Sydney

david.macarthur[at]sydney.edu.au 